\title{
Information about sexual activity after hip replacement: A literature review
}

\section{Sandra Pennbrant ${ }^{1}$, Jeanette Gustafsson Törn² ${ }^{2}$ and Helena Munthe ${ }^{2}$}

\begin{abstract}
Sexual activity is an important aspect of quality of life and contributes to healing and recovery. Adequate information may minimize post-operative risks and improve wellbeing. The aim of this literature review was to identify and review articles regarding the information on sexual activity after hip replacement provided to or obtained by patients and partners prior to their hip replacement surgery. The literature search was performed in the following databases: CINAHL, PubMed/Medline, MEDLINE (via Ebscoost) and Scopus. The results underline the importance of providing hip replacement patients and partners with relevant information, to reduce their concerns and improve their satisfaction and quality of life. Such information could promote person-centered care for patient and partner, and increase long-term cost-effectiveness for the healthcare organization. Information to patients and partners on post-hip-replacement sexual limitations has not been closely studied. Further research is needed to help healthcare providers promote patients' and partners' sexual health and quality of life and improve wellbeing.
\end{abstract}

Keywords hip replacement, information, partner, person-centered care, sexual activity

${ }^{1}$ Department of Health Sciences, University West, Trollhättan, Sweden

${ }^{2}$ Surgeon and Orthopedic Clinic, Kungälvs Hospital, Sweden

Corresponding author:

Sandra Pennbrant, Department of Health Sciences, University West, Gustava

Melins Gata 2, SE-461 86 Trollhättan, Sweden.

Email: sandra.pennbrant@hv.se

\section{Introduction}

Sexual activity is an important aspect of a person's quality of life, over an increasing period, and contributes to life enjoyment, healing and recovery. ${ }^{1-3}$ For instance, hip replacement patients and their partners may have many questions regarding the surgery and its impact on their life situation, including their sex life ${ }^{4-6}$ which if left unanswered may entail unnecessary suffering. ${ }^{7,8}$

According to Maher et al. $^{4}$ adequate information on how to safely resume sexual activity following hip replacement surgery is lacking. Meiri et al. ${ }^{5}$ found that it is beneficial to discuss sexual activity issues with potential hip replacement patients, to identify and discuss the sexual concerns of patients and their partners, and to provide advice on the functional and physical aspects of sexual activity through sexual counseling, therapeutic exercises and advice on sexual positions. Lacking information can entail negative consequences, and cause unnecessary suffering and reduced quality of life. It is therefore important that patients and their partners 
receive adequate information about the surgery, correct joint positioning and the danger of extreme hip flexion and rotation in order to minimize post-operative risks.

\section{Background}

Patients are often worried about the outcomes of medical treatment. Such feelings often entail reduced health-related quality of life. ${ }^{9}$ Quality of life is a subjective and multidimensional indicator encompassing the patient's functional abilities and physical, emotional and social wellbeing, ${ }^{10,11}$ as well as sexual quality of life. ${ }^{1-3}$ The World Health Organization (WHO) defines sexual health as "a state of physical, emotional, mental and social well-being in relation to sexuality”. ${ }^{12}$ Consequently, the quality of a patient's sexual life is important for their general well-being; improvements in a patient's sexual quality of life entail improvements in their general quality of life. ${ }^{12}$ Unresolved sexual difficulties have been found to have a negative impact on patients' and their partners' quality of life. ${ }^{1}$

The concept of person-centered care is internationally acknowledged and can be defined as: “an approach to healthcare that consciously assumes the patient's perspective,” which in turn can be expressed in terms of 'respect for patients' values, preferences, and expressed needs in relation to coordination and integration of care, and continuity”. ${ }^{13}$ According to Leplege et al. ${ }^{14}$ a patient should not be defined based merely on their illness but also on their status as an individual with feelings, knowledge, self-will, social life, values and a will to be involved in their treatment. The implementation of person-centered care raises new expectations on healthcare professionals. ${ }^{15-17}$ The patient's knowledge and understanding of their illness determine the degree and nature of their participation in and influence over their healthcare and treatment. ${ }^{18,19}$ International studies ${ }^{18-21}$ show the potential of care organized and focused around the careseeking person to improve both the clinical outcome of the treatment and the patient's satisfaction with the care received. Furthermore, person-centeredness decreases healthcare costs, although some studies show that the caregivers' short-term costs may increase. ${ }^{22}$

As part of their duties, healthcare professionals are expected to facilitate the patient's learning about their healthcare situation and treatment. ${ }^{6,23}$ To promote the patient's and their partners independence, it is preferable to combine verbal and written information and medical terminology should be avoided. ${ }^{24}$ The purpose of patient-centered care is to make the patient more involved in and responsible for their care and treatment decisions, and for their consequences, which is believed to enhance the patient's and their partner's feeling of safety, satisfaction with the care, and overall quality of life.

As many patients and their partners may hesitate to raise this issue, healthcare professionals should take the initiative to discuss the issue of post-surgery sexual activity. ${ }^{4,6,7}$ Despite this need, 
there is only limited understanding in the healthcare organization about how healthcare providers use and develop the relevant knowledge. ${ }^{1,2}$ Unfortunately, the topic of information to patients and their partners about sexual limitations after hip replacement has not been well studied.

\section{The literature review}

\section{Aim and research question}

The aim of this literature review was to identify and review articles regarding the information on sexual activity after hip replacement provided to or obtained by patients and their partners prior to the hip replacement surgery. The following research question was used: What information is provided?

\section{Search strategy}

A search for relevant articles published between 1 January 1970 and 31 March 2017 was carried out in the following databases: CINAHL, Medline, PubMed/Medline, MEDLINE (via Ebscoost) and Scopus. The search terms included various combinations of the following search terms: activity, expectation*, “arthroplasty, replacement, hip [Mesh]”, hip, "hip arthroplasty”, hip replacement, “total hip replacement”, information*, “intimacy”, “intimate relationship”, “intimate partner”, operation, patient*, "patient education”[All Fields], preoperat*, preoperativ*, “replacement”, sexual, sexual*, “sexuality”, “sexual activity”, “sexual behavior”[Mesh], “sexual partners”. The searches were performed with the assistance of a university librarian.

\section{Inclusion and exclusion criteria}

This study included articles focusing on information to patients and partners on sexual activity after hip replacement. The following types of articles, written in English, were included: empirical studies (quantitative and qualitative), full-text, original research, peer-reviewed.

The following types of articles were excluded: articles covering children, articles not written in English, conference contributions, literature reviews, meta syntheses, and theoretical studies. The database search identified nine articles as being relevant for this study.

\section{Selection process}

The literature review process was conducted in line with the Preferred Reporting Items for Systematic Reviews and Meta-Analyses (PRISMA) guidelines for systematic reviews and the literature review is presented in Figure 1. PRISMA is a minimum set of evidence-based items used for systematic review reporting. ${ }^{25}$ 


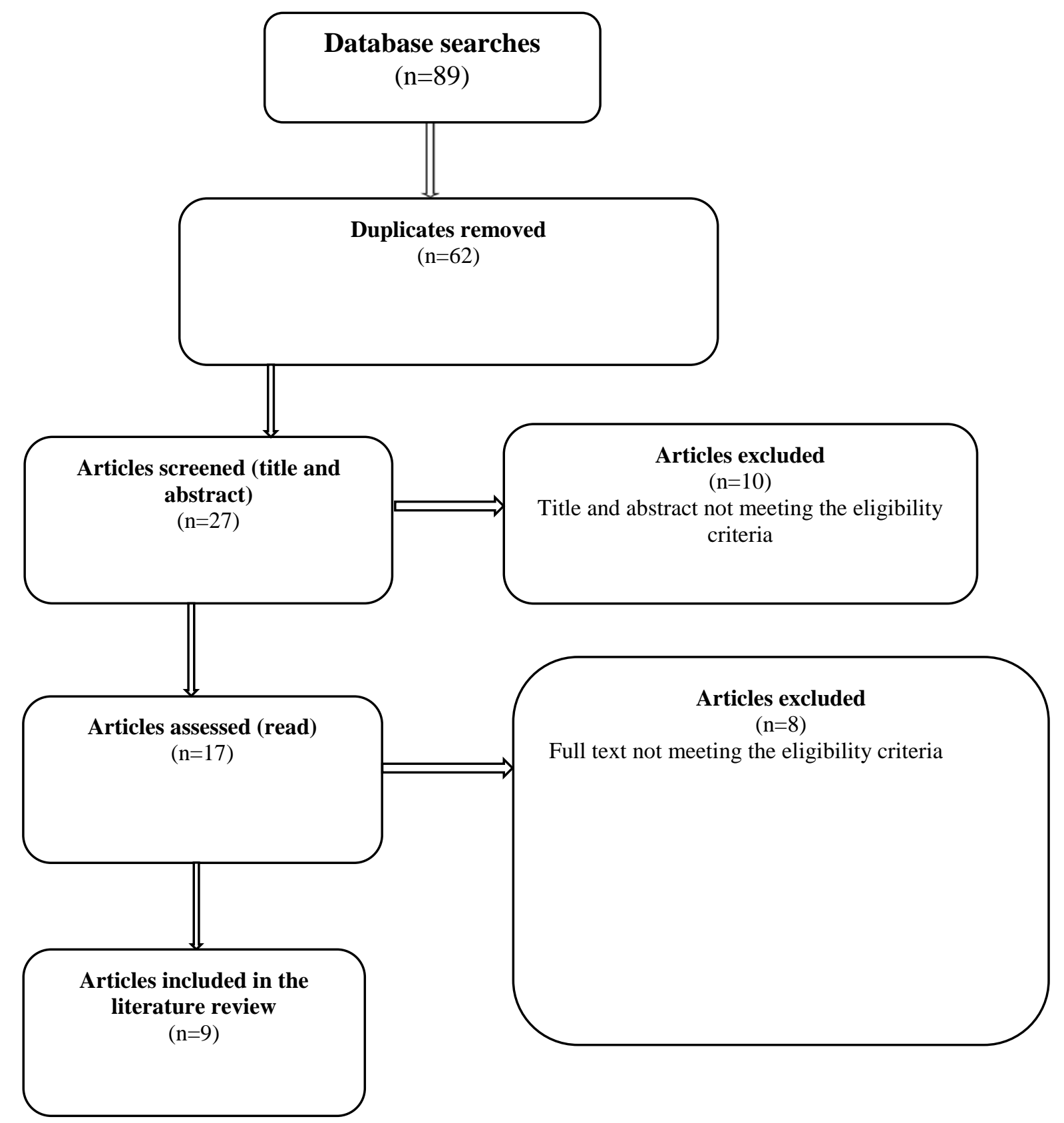

Figure 1. Process of article selection: PRISMA 2009 Flow diagram.

The database searches found 89 articles. After removing duplicates, 27 articles remained. The writers of the paper (SP, JGT and HM) first screened the articles' titles and abstracts to eliminate articles that were not in line with the study's aim. After reading and assessing the remaining 27 articles, 17 articles remained. After excluding articles not meeting the inclusion criteria, nine articles remained as being relevant for the study. An overview of the data content and structure was achieved by categorizing each article's data into a matrix showing the study's participants, methods, measurements, objectives and results. 


\section{Quality appraisal}

We assessed the quality of the selected articles through a quality assessment process. The quality of the studies was evaluated based upon the appropriateness of sampling, i.e. size and methods in relation to study aim, relevance to the setting, reproducibility, risk of bias, use of validated measurement tools and appropriateness of the outcome measures. These indicators were guided by Long et al. ${ }^{26,27}$ for quantitative research studies and for mixed-method studies.

\section{Results}

The nine articles reported study findings from the following countries: UK $(n=3)$, USA ( $n=2)$, France $(n=1)$, Korea $(n=1)$, Sweden $(n=1)$ and Switzerland $(n=1)$. Four of the articles had been published in the 1970-1999 period and five in the 2000-2013 period (Table 1).

Almost all of the studies were hospital-based $(n=8)$; only one study dealt with outpatients. The clinical field was surgery departments. All of the studies were quantitative; one study combined quantitative and qualitative methods. All of the studies were surveys. The studies using questionnaires used specifically-designed questionnaires $(n=2){ }^{28,29}$ Two studies ${ }^{30,31}$ used questionnaires based on those developed for two other studies also included in the review. ${ }^{28,32}$ The studies' objectives concerned problems with post-surgery sexual activity $(n=9)$, time of safe return to sexual activity and safe positions $(n=9)$, and post-surgery childbirth issues $(n=1)$. The sample sizes of the quantitative studies ranged between 53 and 254 .

Five articles comprised a description and discussion of methodological weaknesses. ${ }^{30-34}$ The methodological weaknesses of four of these five articles indicated validity shortcomings. However, all of these five articles carried high informational value and were both representative of the field and relevant for the study's aim. Methodologically weak studies can also contribute interesting insights and knowledge and may therefore be included despite their weaknesses. ${ }^{35}$

\section{Information before surgery}

Baldursson and Brattström ${ }^{29}$ found that it was important to discuss sexual activity before considering hip replacement surgery. Patients should receive information on when they can resume sexual activity after the surgery and on sexual positions to be avoided in the event of prosthesis instability. The probability of hip luxation was believed to be at its highest during the first two to three months following the surgery.

Dahm et al. ${ }^{33}$ found that information was only provided upon patient demand and that patients were in general recommended to resume sexual activity one to three months after surgery.

Stern et al. ${ }^{36}$ and Todd et al. ${ }^{37}$ found that a brochure should be used to provide information about sexual activity after hip replacement. Currey ${ }^{28}$ found that $48 \%$ of the patients preferred to 
receive a brochure on the issue and Wall et al. ${ }^{34}$ found that patients received written advice about the appropriate time for resuming sexual activity.

\section{Information about risk of dislocation}

Yoon et al. ${ }^{31}$ found that the risk of dislocation was patients' most common concern in the context of post-surgery sexual activity, and that $80 \%$ of the patients had been unable to obtain information on the resumption of sexual activity after hip replacement (39\% of the patients had experienced leg-positioning problems during sexual activity).

Four of the nine articles found that that patients should receive information on the resumption of sexual activity following their hip replacement surgery. ${ }^{30,31,33,34}$

In general, it is also crucial that patients follow the instructions received in their movement program in order to avoid hip luxation. ${ }^{33,34}$

Lafosse et al. ${ }^{30}$ found that $10.5 \%$ of the patients surveyed had received verbal information, that only $21 \%$ of the patients had received information on sexual positions to be avoided, and that the verbal information should be combined with a brochure. Wall et al. ${ }^{34}$ found that $72 \%$ of the patients surveyed had been recommended to wait for six months before resuming post-surgery sexual activity and that $55 \%$ of the patients wanted to receive more information than the healthcare professionals had provided. Meyer et al. ${ }^{32}$ also found that most patients and their partners preferred to receive information on safe resumption of sexual activity after hip replacement surgery via brochures or the internet. This preference is likely due to the sensitive nature of sexual activity.

Yoon et al. ${ }^{31}$ found that most patients had not discussed the issue because they considered it to be too personal; and that they had obtained the relevant information from the internet instead. Therefore, the internet is the most frequent source of information about sexual activity after hip replacement surgery.

Currey ${ }^{28}$ found that the lack of information on when sexual activity could be resumed made some female patients refrain from such activity out of fear of damaging their replaced hip. Stern et al. ${ }^{36}$ and Dahm et al. ${ }^{33}$ presented similar results.

Meyer et al. ${ }^{32}$ found that female patients wanted information on which sexual positions are safe after hip replacement surgery and on the surgery's impact on their sex life, that the hip replacement surgery had affected the quality of the sexual relations of female patients, and that more than half (57\%) of the women surveyed had waited for four months or more before resuming sexual activity as they had received no information about when such activity could be safely resumed. 
Table 1. Included articles.

\begin{tabular}{|c|c|c|c|c|c|c|}
\hline $\begin{array}{l}\text { Author } \\
\text { (Publication } \\
\text { year) } \\
\text { Country } \\
\end{array}$ & Participants & Methods & Measurements & Objectives & $\begin{array}{l}\text { Bias } \\
\text { risk }\end{array}$ & Results \\
\hline $\begin{array}{l}\text { Baldursson \& } \\
\text { Brattström } \\
(1979) \\
\text { Sweden }\end{array}$ & $\begin{array}{l}53 \text { patients } \\
\text { (40 women } \\
\text { and } 13 \text { men) } \\
\text { Surgical } \\
\text { hospital care }\end{array}$ & $\begin{array}{l}\text { Descriptive } \\
\text { quantitative } \\
\text { questionnaire }\end{array}$ & $\begin{array}{l}\text { Descriptive } \\
\text { statistics } \\
\text { The questionnaire } \\
\text { was designed for } \\
\text { this study }\end{array}$ & $\begin{array}{l}\text { Sexual } \\
\text { problems } \\
\text { connected } \\
\text { with hip } \\
\text { disease in a } \\
\text { group of } \\
\text { patients with } \\
\text { rheumatoid } \\
\text { arthritis }\end{array}$ & High & $\begin{array}{l}\text { Great importance to } \\
\text { discuss sexual problems } \\
\text { with the patient when } \\
\text { hip surgery is being } \\
\text { contemplated. } \\
\text { Fear of damaging the } \\
\text { prosthesis }\end{array}$ \\
\hline $\begin{array}{l}\text { Currey } \\
(1970) \\
\text { UK }\end{array}$ & $\begin{array}{l}121 \text { patients } \\
\text { (73 women } \\
\text { and } 48 \text { men) } \\
\text { (60 years or } \\
\text { younger) }\end{array}$ & $\begin{array}{l}\text { Descriptive } \\
\text { quantitative } \\
\text { postal } \\
\text { questionnaire }\end{array}$ & $\begin{array}{l}\text { Descriptive } \\
\text { statistic } \\
\text { The questionnaire } \\
\text { was designed for } \\
\text { this study }\end{array}$ & $\begin{array}{l}\text { Impact of } \\
\text { operation on } \\
\text { sex life }\end{array}$ & High & $\begin{array}{l}\text { Advice and information } \\
\text { about sexual activity } \\
\text { from family doctor, } \\
\text { physician at hospital } \\
\text { and brochure }\end{array}$ \\
\hline $\begin{array}{l}\text { Dahm, } \\
\text { Jacofsky } \\
\text { \& Lewallen } \\
\text { (2004) } \\
\text { USA }\end{array}$ & $\begin{array}{l}254 \text { members } \\
\text { of the } \\
\text { American } \\
\text { Association of } \\
\text { Hip and Knee } \\
\text { Surgeons }\end{array}$ & $\begin{array}{l}\text { Survey study } \\
\text { Descriptive } \\
\text { quantitative } \\
\text { questionnaire }\end{array}$ & $\begin{array}{l}\text { Descriptive } \\
\text { statistics } \\
\text { Wilcoxon signed- } \\
\text { rank test, } \\
\text { Wilcoxon rank } \\
\text { sum test, Fisher’s } \\
\text { exact test, } \\
\text { Kruskal-Wallis } \\
\text { test, Spearman's } \\
\text { rank correlation } \\
\text { coefficient. A } \\
\text { significance level } \\
\text { of } 0.05 \text { was used } \\
\text { for all statistical } \\
\text { tests. }\end{array}$ & $\begin{array}{l}\text { Hip surgeons } \\
\text { experience } \\
\text { regarding } \\
\text { their opinions } \\
\text { on appropriate } \\
\text { guidelines for } \\
\text { safe return to } \\
\text { sexual activity } \\
\text { after a total } \\
\text { hip } \\
\text { arthroplasty }\end{array}$ & Medium & $\begin{array}{l}\text { Rarely or never discuss } \\
\text { sexual activity with the } \\
\text { patient. Lack of } \\
\text { information }\end{array}$ \\
\hline $\begin{array}{l}\text { Lafosse, } \\
\text { Tricoire, } \\
\text { Chiron \& } \\
\text { Puget } \\
\text { (2007) } \\
\text { France }\end{array}$ & $\begin{array}{l}135 \text { patients } \\
\text { (58 women } \\
\text { and } 77 \text { men) } \\
\text { under } 65 \text { years }\end{array}$ & $\begin{array}{l}\text { Quantitative } \\
\text { questionnaire } \\
\text { Retrospective } \\
\text { survey using } \\
\text { the items from } \\
\text { Currey (1970) } \\
\text { and Meyer et } \\
\text { al. (2003). } \\
\text { Questionnaire } \\
\text { s, } \\
\text { combined } \\
\text { with a reduced } \\
\text { WOMAC } \\
\text { function scale }\end{array}$ & $\begin{array}{l}\text { Descriptive } \\
\text { statistic } \\
\text { 5-point Lickert } \\
\text { scale. Non- } \\
\text { parametric. } \\
\text { Wilcoxon test, } \\
\text { Mann-Whitney U- } \\
\text { test, Chi- } \\
\text { squared test, } \\
\text { Exact Fisher test }\end{array}$ & $\begin{array}{l}\text { Sexual } \\
\text { difficulties of } \\
\text { patients } \\
\text { before and } \\
\text { after hip } \\
\text { replacement } \\
\text { surgery. } \\
\text { Degree of } \\
\text { information } \\
\text { provision }\end{array}$ & Low & $\begin{array}{l}\text { Lack of information on } \\
\text { sexual activity before } \\
\text { and/or after hip } \\
\text { replacement. } \\
\text { Sexual difficulties } \\
\text { should be taken into } \\
\text { account by medical staff }\end{array}$ \\
\hline $\begin{array}{l}\text { Meyer, Stern, } \\
\text { Fusetti, } \\
\text { Salsano, } \\
\text { Campana \& } \\
\text { Hoffmeyer } \\
\text { (2003) } \\
\text { Switzerland } \\
\end{array}$ & $\begin{array}{l}60 \text { women } \\
\text { (14-59 years) }\end{array}$ & $\begin{array}{l}\text { Retrospective } \\
\text { quantitative } \\
\text { review }\end{array}$ & $\begin{array}{l}\text { Descriptive } \\
\text { statistic } \\
\text { The questionnaire } \\
\text { was designed for } \\
\text { this study }\end{array}$ & $\begin{array}{l}\text { To study the } \\
\text { effect of } \\
\text { reconstructive } \\
\text { hip surgery on } \\
\text { the quality of } \\
\text { sexual } \\
\text { relations in } \\
\text { women }\end{array}$ & Medium & $\begin{array}{l}\text { Lack of information } \\
\text { regarding sexual } \\
\text { activity and safe sex } \\
\text { positions }\end{array}$ \\
\hline $\begin{array}{l}\text { Stern, Fuchs, } \\
\text { Ganz, Classi, } \\
\text { Sculco \& } \\
\text { Salvati } \\
\text { (1991) } \\
\text { USA }\end{array}$ & $\begin{array}{l}86 \text { patients } \\
\text { (47 women } \\
\text { and } 39 \text { men) }\end{array}$ & $\begin{array}{l}\text { Descriptive } \\
\text { quantitative } \\
\text { questionnaire }\end{array}$ & $\begin{array}{l}\text { Descriptive } \\
\text { statistic } \\
\text { Statistical } \\
\text { analysis. Fisher's } \\
\text { exact chi-square, } \\
t \text {-test }\end{array}$ & $\begin{array}{l}\text { Study impact } \\
\text { of operation } \\
\text { on sexual } \\
\text { function, time } \\
\text { frame for safe } \\
\text { return to } \\
\text { sexual activity } \\
\text { and safe } \\
\text { positions }\end{array}$ & High & $\begin{array}{l}\text { Lack of information } \\
\text { regarding safe return to } \\
\text { sexual activity after hip } \\
\text { replacement. } \\
\text { Information from } \\
\text { brochure, surgeon and } \\
\text { physicians }\end{array}$ \\
\hline
\end{tabular}


Table 1. Continued.

\begin{tabular}{|c|c|c|c|c|c|c|}
\hline $\begin{array}{l}\text { Author } \\
\text { (Publication } \\
\text { year) } \\
\text { Country }\end{array}$ & Participants & Methods & Measurements & Objectives & Bias risk & Results \\
\hline $\begin{array}{l}\text { Todd, } \\
\text { Lightowler \& } \\
\text { Harris } \\
\text { (1973) } \\
\text { UK }\end{array}$ & $\begin{array}{l}79 \text { patients } \\
\text { (43 women and } \\
36 \text { men) }\end{array}$ & $\begin{array}{l}\text { Descriptive } \\
\text { quantitative } \\
\text { questionnaire } \\
\text { and } \\
\text { semi-structured } \\
\text { interview }\end{array}$ & $\begin{array}{l}\text { Descriptive } \\
\text { statistics }\end{array}$ & $\begin{array}{l}\text { Sexual } \\
\text { problems due } \\
\text { to hip joint } \\
\text { disease }\end{array}$ & High & $\begin{array}{l}\text { Lack of } \\
\text { information } \\
\text { regarding } \\
\text { sexual activity. } \\
\text { Patients } \\
\text { preferred to } \\
\text { receive info in } \\
\text { the form of a } \\
\text { booklet. }\end{array}$ \\
\hline $\begin{array}{l}\text { Wall, Hossain, } \\
\text { Ganapathi \& } \\
\text { Andrew } \\
\text { (2011) } \\
\text { UK }\end{array}$ & $\begin{array}{l}86 \text { patients (47 } \\
\text { women and } 39 \\
\text { men) and } 83 \\
\text { surgeons }\end{array}$ & $\begin{array}{l}\text { Questionnaire } \\
\text { survey }\end{array}$ & $\begin{array}{l}\text { Descriptive } \\
\text { statistics. } \\
\text { 4-point Likert } \\
\text { scale } \\
\text { questionnaire }\end{array}$ & $\begin{array}{l}\text { Determine the } \\
\text { importance of } \\
\text { regaining } \\
\text { sexual for } \\
\text { patients } \\
\text { undergoing } \\
\text { total hip } \\
\text { arthroplasty } \\
\text { (THA) }\end{array}$ & Low & $\begin{array}{l}\text { Information } \\
\text { needed } \\
\text { regarding } \\
\text { sexual activity } \\
\text { after total hip } \\
\text { arthroplasty. } \\
\text { Value of } \\
\text { written } \\
\text { information } \\
\end{array}$ \\
\hline $\begin{array}{l}\text { Yoon, Lee, } \\
\text { Noh, Ha, Lee } \\
\text { \& Koo } \\
\text { (2013) } \\
\text { Korea }\end{array}$ & $\begin{array}{l}64 \text { patients } \\
\text { (women } 19 \text { and } \\
45 \text { men) at an } \\
\text { outpatient } \\
\text { clinic }\end{array}$ & $\begin{array}{l}\text { Questionnaire } \\
\text { administered } \\
\text { during a face- } \\
\text { to-face } \\
\text { interview } \\
\text { based on } \\
\text { Currey (1970) } \\
\text { and Meyer et } \\
\text { al. (2003) }\end{array}$ & $\begin{array}{l}\text { Descriptive } \\
\text { statistics } \\
\text { Fisher's exact } \\
\text { test }\end{array}$ & $\begin{array}{l}\text { Determine } \\
\text { what the } \\
\text { concerns of } \\
\text { patients related } \\
\text { to sexual } \\
\text { activity after } \\
\text { total hip } \\
\text { arthroplasty } \\
\text { are and what } \\
\text { the changes in } \\
\text { sexual activity } \\
\text { after total hip } \\
\text { replacement in } \\
\text { Korean } \\
\text { patients are }\end{array}$ & Low & $\begin{array}{l}\text { Difficulties } \\
\text { with leg } \\
\text { positioning } \\
\text { following total } \\
\text { hip } \\
\text { replacement. } \\
\text { Fear of } \\
\text { dislocation. } \\
\text { Lack of } \\
\text { information. } \\
\text { Patient did not } \\
\text { consult with a } \\
\text { physician. } \\
\text { Private nature } \\
\text { of the topic. }\end{array}$ \\
\hline
\end{tabular}

\section{Discussion}

The aim of this study was to identify and review articles regarding the information on sexual activity after hip replacement provided to or obtained by patients and their partners prior to hip replacement surgery.

Patients and their partners want to receive more information on the issue of sexual activity after hip replacement but find the issue embarrassing. Lieberman et al. ${ }^{38}$ noted that most of the standard hip scoring systems or current self-assessment tools did not address the patient's sexual activities. This confirms Baldursson and Brattström's ${ }^{29}$ observation that the information about sexual activity is insufficient. Patients tend to wait longer (four months-never) before resuming sexual activity. A combination of verbal and written information is to be preferred. If patients' knowledge needs are not met this can entail negative consequences for their hip prosthesis and unnecessary suffering for the patient and their partner. ${ }^{24}$

The information in question should cover the time of safe return to sexual activity and the sexual positions to be avoided. By initiating the provision of information on the resumption of 
sexual activity, healthcare professionals can lower the patients' stress level, both before and after the hip replacement surgery, and improve both their satisfaction with the treatment and their overall well-being. A valuable method of initiating information and discussion on the issue of resumed sexual activity following hip replacement surgery can be to provide written information well in advance of a patient-partner-healthcare professional meeting. One approach for healthcare professionals to bridge this information gap can be to implement person-centered care ${ }^{16,18,20-22}$ combined with a pedagogical and reflective demeanor in order to reduce the patient's suffering and promote their well-being. ${ }^{24}$ During the meeting with the patient and partner, and in particular in the context of discussion about post-hip replacement sexual activity, it is crucial that healthcare professionals promote a good and safe relationship with the patient and partner, thus allowing open discussion and questioning about the sensitive issue of sexual activity. ${ }^{18,20-22,24}$ To achieve such good quality of meeting, healthcare professionals should, prior to the meeting, carefully consider the actual patient and partner, the sensitive subject to be covered during the meeting, and have a clear and specific goal for the meeting. The healthcare professional should come to the meeting with a clear agenda listing all the relevant items with which the patient and partner need be familiar, should allow a free and open discussion between the parties, and should be very attentive to the patient's and partner's needs and concerns in terms of post-hip replacement sexual activity. $^{4-7}$

Sexuality is a complex aspect of being human. There are many reasons patients and their partners lack basic information on how to handle sexual issues in connection with hip replacement. To support patients and partners with their sexual rehabilitation, healthcare professionals need to cooperate and take into account a wide range of patient-dependent biological, psychological and sociological factors. ${ }^{5}$

Considering the sensitive nature of the information and discussion, healthcare professionals should be particularly mindful that their demeanor and social competence may affect the patient and partner negatively (or positively), may create boundaries and barriers between the people involved, and may make it difficult to create a holistic view of the individual patient. According to Ekman et al. ${ }^{16}$ organizational flexibility is a key factor for person-centered care.

Collaboration between healthcare professionals requires that participants come to realize the importance of developing shared skills for the sake of achieving person-centered care. By applying person-centered care, opportunities for new way of thinking could promote an open mind and thus both deepen and broaden the understanding of patients' health problems, their needs and resources. ${ }^{39}$

The result of this literature review is consistent with the narrative review conducted by Meiri et al. ${ }^{5}$ and confirms their conclusion that better education is needed regarding sexual activity after 
total hip replacement. There seems to be a need to de-dramatize the issue of resumed sexual activity and discussion thereof.

First, well upstream of the actual decision to perform hip replacement surgery, healthcare professionals should provide the patient and partners with brochures and appropriate internet links covering the issue of post-hip replacement sexual activity. By encouraging patients to independently learn about hip replacement and its effects on sexual activity, the issue can be rendered less sensitive when the time comes to actually discuss it with healthcare professionals.

Second, when hip replacement becomes a serious clinical option, the healthcare professionals should schedule and hold a meeting (if need be several meetings) with the patient and partner about the impact of hip replacement on the patient's life situation in general and on their sex life in particular. By intentionally dedicating time to the issue of sexual activity, the patient and partner are guaranteed an opportunity to consider the information, ask questions, and correctly and fully absorb the information.

Third, healthcare professionals should explore whether the patient feels appropriately informed by the written materials they have received and the internet. This 'feedback loop' would enable healthcare professionals, as a group, to adapt to the patients and partner's learning ability and needs, and to improve their own knowledge and understanding of the issues at hand.

This information and learning sequence complies with the finding of this study and with the insight that healthcare professionals have an important role to play when it comes to informing and educating patients, as well as partners, and ascertaining their correct understanding of the information provided, and that a combination of verbal and written information is to be preferred in the meeting. ${ }^{24}$

Patients and their partners appreciate receiving brochures on the issue and consult the internet when healthcare professionals do not provide sufficient information. Obviously, all written information provided and all internet sources must be up to date and well designed. One study ${ }^{40}$ found that the quality of hip precaution literature can vary greatly, and that such literature should provide contact details for help, use good quality diagrams, and suggest further reading. Due to the sensitive nature of the subject matter at hand, it may be helpful to involve hip replacement patients and partners in the design of the written and internet-based informational materials on resumed sexual activity following hip replacement surgery.

By encouraging healthcare professionals to have a person-centered care perspective and see the patient as an individual, one increases the likelihood of understanding the patient's concerns, needs and situation, and thus of providing appropriate and targeted advice, information and support. 


\section{Summary of recommendations}

The results of this literature review can be used to develop and promote:

- Awareness of present and future healthcare professionals about the importance of providing information on resumed sexual activity to patients and partners who are about to or have undergone hip replacement surgery.

- Informational brochures and internet sites for patients and partners on the resumption of sexual activity following hip replacement surgery.

- Guidelines for healthcare professionals on their meetings and discussions with patients and partners about the resumption of sexual activity following hip replacement surgery.

- Training materials for present and future healthcare professionals on the importance and practice of providing information on resumed sexual activity to hip replacement patients and partners.

\section{Study limitations}

This study was based on the nine articles available at the time of the literature search. This limited number of articles shows that there is probably a knowledge gap in this particular area and may reduce the value of this study's practical conclusions. However, the nature of a literature review is not determined by the number of articles included; the key issue is whether or not all relevant articles are included in the study. ${ }^{41}$ The review comprised articles from various journals and cultures including non-English-speaking countries. When a phenomenon, in this case sexuality in the context of hip replacement, is strongly connected to cultural values, it may be claimed that it is not meaningful to study articles from very different countries and times. However, in this study, the articles' findings and conclusions were similar, despite their varied cultural backgrounds, which indicates that the issue and challenges at hand may be shared between cultures. The use of several databases also decreased the risk of bias in the search. Nevertheless, the fact that so few articles were identified confirms the study's overall conclusion that hip replacement patients and their partners do not receive sufficient information on the resumption of sexual activity; a shortcoming that negatively impacts their quality of life.

\section{Conclusion}

It emerged that patients do not receive enough information on the issue of sexual activity after hip replacement, that both patients and healthcare professionals find the topic to be embarrassing, and that a combination of oral and written information is preferred. The importance and the sensitivity of the issue make it a worthwhile area for further study and for attention implementing 
a perspective combining the insights and approaches of person-centered care to help healthcare providers promote patients’ and partners’ quality of life and improve their well-being.

\section{Acknowledgements}

The authors thank Patrick Reis for his editing and proofreading assistance.

\section{Funding}

This research received no specific grant from any funding agency in the public, commercial, or not-for-profit sectors.

\section{Conflict of interest}

The authors declare that there is no conflict of interest.

\section{References}

1. Hulter B. Sexualitet och hälsa - begränsningar och möjligheter. [Sexuality and Health Constraints and Opportunities]. Lund: Studentlitteratur, 2004, pp.319.

2. Sundbeck M. Sexuell hälsa i vården - En metodbok för sjuksköterskor. [Sexual Health in Healthcare - A Method Book for Nurses]. Lund: Studentlitteratur, 2013, pp.186.

3. World Health Organization (WHO). Gender and human rights. 2014. Available at: http://www.who.int/reproductivehealth/topics/gender_rights/sexual_health/en/. Accessed November 10, 2016.

4. Maher AB, Salmond SW, Pellino TA. Orthopedic nursing: degenerative disorder. (3rd ed.), Philadelphia: Saunders, 2005, pp.303.

5. Meiri R, Rosenbaum TY, Kalichman L. Sexual function before and after total hip replacement: Narrative review. Sex Med 2014; 2(4): 159-167. DOI:10.1002/sm2.35

6. Socialstyrelsen [Swedish National Board of Health and Welfare]. Svenska höftprotesregistret [Swedish hip prosthesis register]. Stockholm: Socialstyrelsen, 2010, pp. 2. Available at: http://www.shpr.se/Libraries/Documents/AnnualReport2009.sflb.ashx. Accessed 10 November 2016

7. Lavernia CJ, Villa JM. High Rates of Interest in Sex in Patients With Hip Arthritis. Clin Orthop Relat Res 2016; 474(2): 293-299. Published online: 08 July. DOI: 10.1007/s11999-015-4421-8

8. Charbonnier C, Chagué S, Ponzoni M, Bernardoni M, Pierre Hoffmeyer P, Christofilopoulos P. Sexual Activity After Total Hip Arthroplatsy: A Motion Capture Study. J Arthroplasty 2014; 29(3): 640-647. 
9. Rolfson O, Dahlberg LE, Nilsson JA, Malchau H, Garellick G. Variables determining outcome in total hip replacement surgery. J Bone Joint Surg Br 2009; 91(2): 157-161. DOI: 10.1302/0301-620X.91B2.20765

10. Azzopardi S, Lee G. Health-related quality of life 2 years after coronary artery bypass graft surgery. $J$ Cardiovasc Nurs 2009; 24(3): 232-240. DOI: 10.1097/JCN.0b013e31819b2125

11. Cella DF. Quality of life: Concepts and definition. J Pain Symptom Manage, 1994; 9: 186-192.

12. World Health Organization (WHO). Defining sexual health. Report of a technical consultation on sexual health, 28-31 January 2002, Geneva. Available at: http://www.who.int/reproductivehealth/publications/sexual_health/defining_sexual_health .pdf. Accessed 2 April 2017

13. The United States Agency for International Development (USAID). U.S: Government Agency, 1999. Available at: https://www.usaid.gov/. Accessed 10 November 2016

14. Leplege A, Gzil F, Cammelli M, Lefeve C, Pachoud B, Ville I. Person-centeredness: Conceptual and historical perspectives. Disabil Rehabil 2007; 29(20-21): 1555-1565.

15. McCormack B, McCance T. Person-Centered Nursing: Theory and Practice. Oxford: Wiley-Blackwell, 2010, pp.194.

16. Ekman I, Swedberg K, Taft C, Lindseth A, Norberg A, Brink E, Carlsson J, DahlinIvanoff S, Johansson IL, Kjellgren K, Lidén E, Öhlén J, Olsson LE, Rosén H, Rydmark M, Sunnerhagen KS. Person-centered care - ready for prime time. Eur J Cardiovasc Nurs 2011; 10(4): 248-251. PMID: 21764386.

17. Socialstyrelsen [Swedish National Board of Health and Welfare]. Nationella indikatorer för god vård [National Indicators of Good Health]. Socialstyrelsen: Stockholm, 2009, pp. 87. Available at: http://www.socialstyrelsen.se/publikationer. Accessed 10 November 2016.

18. Groene O. Patient Centeredness and Quality Improvement Efforts in Hospitals: Rationale, Measurement, Implementation. Int J Qual Health Care 2011; 23(5): 531-537.

19. Socialstyrelsen [Swedish National Board of Health and Welfare]. De mest sjuka äldre. [The most sick elderly]. Stockholm: Socialstyrelsen, 2011, pp. 23. Available at: http://www.socialstyrelsen.se/publikationer. Accessed 10 November 2016.

20. Dubois CA, Singh D, Jiwani I. The human resource challenge in chronic care. In E Nolte and CM McKee (eds) Caring for people with chronic conditions. A health system perspective. Berkshire: Open University Press, 2008, pp.143-171. 
21. van Royen P, Beyer M, Chevallier P, Eilat-Tsanani S, Lionis C, Peremans L, ... Hummers-Pradier E. The research agenda for general practice/family medicine and primary health care in Europe. Part 3. Results: person centred care, comprehensive and holistic approach. Eur J Gen Pract 2010; 16(29): 113-119.

22. Agency for Healthcare Research and Quality (AHRQ). National Healthcare Quality Report. USA: Rockville, 2011, pp. 230.

23. Pilhammar Andersson E, Bergh M, Friberg F, Gedda B, Häggström E. Pedagogik inom vård och omsorg [Education in health and social care]. Lund: Studentlitteratur, 2003, pp.172.

24. Bülow P, Persson Thunqvist D, Sandén I. Delaktighetens praktik. Det professionella samtalets villkor och möjligheter [The practice of participation. Conditions and opportunities of the professional talk]. Sweden: Gleerups, 2012, pp.192.

25. Moher D, Liberati A, Tetzlaff J, Altman DG. Preferred Reporting Items for Systematic Reviews and Meta-Analyses: the PRISMA Statement. PLoS Medicine, 2009;6:e1000097. DOI:10.1371/journal.pmed1000097

26. Long AF, Godfrey M, Randall T, Brettle AJ, Grant MJ. Evaluation Tool for Quantitative Research Studies. School of Healthcare, University of Leeds, 2002.

27. Long A. Evaluation Tool for Mixed Methods Studies. School of Healthcare, University of Leeds, 2005.

28. Currey HLF. Osteoarthrosis of the hip joint and sexual activity. Ann Rheum Dis 1970; 29: 488-493.

29. Baldursson H, Brattström H. Sexual difficulties and total hip replacement in reumatoid arthritis. Scand J Rheumatol 1979; 8(4): 214-216.

30. Lafosse JM, Tricoire JL, Chiron P, Puget J. Sexual function before and after primary total hip arthroplasty. Joint Bone Spine 2008; 75(2): 189-194.

31. Yoon BH, Lee KH, Noh S, Ha YC, Lee YK, Koo KH. (2013). Sexual activity after total hip replacement in Korean Patients: How they do, what they want, and how to improve. Clin Orthop Surg 2013; 5(4): 269-277. Doi: 10.4055/cios.2013.5.4.269

32. Meyer H, Stern R, Fusetti C, Salsano F, Campana A, Hoffmeyer P. Sexual quality-of-life after hip surgery. J Orthop Traumatol 2003; 4: 21-25. DOI: 10.1007/s101950300003

33. Dahm DL, Jacofsky D, Lewallen DG. Surgeons Rarely Discuss Sexual Activity with Patients after THA. Clin Orthop Relat Res 2004; 428: 237-240.

34. Wall PDH, Hossain M, Ganapathi M, Andrew JG. Sexual activity and total hip arthroplasty: a survey of patients’ and surgeons’ perspectives. Hip Int 2011; 21(1-2): 99205. DOI:10.5301/HIP.2011.6518 
35. Sandelowski M, Barroso J. Classifying the findings in qualitative studies. Qualitative Health Research 2003; 13(7): 905-923.

36. Stern SH, Fuchs MD, Ganz SB, Classi P, Sculco TP, Salvati EA. Sexual Function After Total Hip Arthroplasty. Clin Orthop Relat Res 1991; 269: 227-235.

37. Todd RC, Lightowler CDR, Harris J. Low friction arthroplasty of the hip joint and sexual activity. Acta Orthop Scand 1973; 44(6): 690-693.

38. Lieberman JR, Thomas BJ, Finerman GA, Dorey F. Patients’ reasons for undergoing total hip arthroplasty can change over time. J Arthroplasty 2003; 18(1): 63-68.

39. Dahlborg Lyckhage E, Pennbrant S. Work-Integrated Learning A Didactic Tool to Develop Praxis in Nurse Education. ANS Adv Nurs Sci 2014; 37(1): 61-69. DOI: 10.1097/ANS.0000000000000018

40. Drummond A, Edwards C, Coole C, Brewin C. What do we tell patients about elective total hip replacement in the UK? An analysis of patient literature. BMC Musculoskeletal Disorders 2013; 14(1): 152. DOI: 10.1186/1471-2474-14-152

41. Forsberg C, Wengström Y. Att göra systematiska litteraturstudier - Värdering, analys och presentation av omvårdnadsforskning [Making systematic literature reviews Measurement, analysis and presentation of nursing research]. Stockholm: Natur och kultur, 2008, pp.215. 